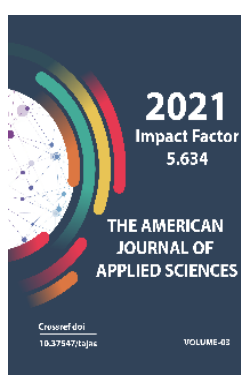

Journal Website: http://usajournalshub.c om/index,php/tajas

Copyright: Original content from this work may be used under the terms of the creative commons attributes 4.0 licence.

\section{The Results Of The Study Of Indicators Of The Syndrome Of Endogenous Intoxication In Patients With Seroresistance In Syphilis}

\author{
K.A Yuldashev \\ Professor, RSNPMC Dermatovenereology And Cosmetology Of The Ministry Of Health Of The \\ Republic Of Uzbekistan
}

\author{
K.M. Abzoirov \\ RSNPMC Dermatovenereology And Cosmetology Of The Ministry Of Health Of The Republic \\ Of Uzbekistan
}

\title{
ABSTRACT
}

This article discusses patients with serorresis syphilis obtained as an additional - tion treatment by the following procedures: I - group (33.9\%) were treated with penicillin for 1 Mill. U every 6 hours to a total dose - 120 million units;. Group II (26.3\%) received treatment with ceftriaxone 1.0 intramuscularly 1 time per day for 16 days (amount - 16.0); Group III (39.8\%) with ceftriaxone 1.0 daily for 16 days (16.0). In venereology, the problem of syphilitic seroresistance is of great importance. In addition, the study of the causal factors in the development of seroresis in syphilis is an important direction in science.

\section{KEYWORDS}

Patients, serorresis syphilis, penicillin, syphilitic seroresistance, causal factors, important direction, serological blood, reactions.

\section{INTRODUCTION}

The Research made in 121 patients with seroresis at B - Phyllis from 2 years to 15 years. The patients' age ranged from 19 to 64 years.
Female was $-52,8 \%$ of men $-47,2 \%$. At the age of up to 20 years, there were 5 patients, from 21 to 30 years old - 44,31 - 40 years old - 2441 - 
50 years old $-23,41$ - 60 years old - 20,61 years old and 5 people older (graph 1).

The complex serological blood reactions included: reaction of Wasserman and with cardiolipin and treponemal $\mathrm{E}$ antigens microreaction $(\mathrm{m} / \mathrm{p}$ ) of the specific reactions - the reaction of immunofluorescence in two modifications - IEF - 200 RIF - abs and reaction immobilization pale treponem (RIBT).

To determine the indicators of endogenous intoxication, the following were used: determination of the level of medium molecular weight peptides (SMP), according to the method of Gabrielyan N.I. (1983); the sorption capacity of erythrocytes ( ESE) was determined by the method of A.A. Togaybaev et al. (1988); leukocyte intoxication index (LII) was investigated by the method of Kalf- Calif Ya, Ya. (1969); hematological index of intoxication (GII) was studied according to the method of V.S. Vasiliev , V.I. Komar (1983)

\section{THE MAIN FINDINGS AND RESULTS}

Patients and seroresis syphilis distributed by lane - the Primary diagnosed: at 12 - beat defined primary Serop - transitivity , 11 secondary fresh, 64 - early latent, 30 secondary recurrent, 4 patients - late latent syphilis ...

According to the initially established diagnoses, the patients received the following treatment: benzathine- penicillin - 67 (55.4\% of patients ), penicillin - 27 (22,3\%), bicillins - 3 and $5-12$ (9.9\%) and reserve antibiotics - 15 (12.4\%) patients.

In the blood of patients with seroresis prior to additional treatment positivity serological marked Reaction Wasserman with cardiolipin antigen - $91 \%$, with ultrazvuchnym - $89 \%$, the micro - reaction - $100 \%$, of the specific - IEF - 200 - $96 \%$, RIF- abs - in $96.6 \%$, RIBT - in $91.3 \%$ of cases.

Schedule 1

Distribution of patients with seroresistance by sex and age

Patients with serorresis syphilis obtained as an additional - tion treatment by the following procedures: I - group (33.9\%) were treated with penicillin for 1 Mill. $U$ every 6 hours to a total dose - 120 million units;. Group II (26.3\%) received treatment with ceftriaxone 1.0 intramuscularly 1 time per day for 16 days (amount - 16.0); Group III (39.8\%) with ceftriaxone 1.0 daily for 16 days (16.0). In this case, ceftriaxone was administered by an indirect lymphotropic method. The drug was injected into the gastrocnemius muscle, intramuscularly, creating pressure $(60 \mathrm{~mm} \mathrm{Hg})$.

Schedule 2

Additional treatment for patients with seroresistance in syphilis

Development seroresis when syphilis is caused by many factors, among which not the last role is played by the phenomena of endogenous Foot toxicity of the body. In this regard, studied the state of the endo syndrome genetic toxicity by determining the level: of middle Pep - tidov NSR), the sorption of red blood cells ability (ESA), leukocyte intoxication index (LII) and gemotological indicator of intoxication ( $\mathrm{GPI}$ ) in 121 patients with seroresistance before and after additional treatment 
Table 1

Indicators of endogenous intoxication in patients with seroresistance

\begin{tabular}{|c|c|c|c|}
\hline \multirow{2}{*}{$\begin{array}{l}\text { Indicators } \\
\text { Endogenous } \\
\text { intoxication }\end{array}$} & \multirow[t]{2}{*}{ Control group } & \multicolumn{2}{|c|}{ Indicators of endotoxicosis in seroresistance } \\
\hline & & Before treatment & After treatment \\
\hline SSE & $31.7 \pm 0.64$ & $51.6 \pm 0.7$ & $30.43 \pm 0.62$ \\
\hline SMP & $0.22 \pm 90.001$ & $0.38 \pm 0.002$ & $0.31 \pm 0.0018$ \\
\hline LII & $1.215 \pm 0.04$ & $1.91 \pm 0.12$ & $1.75 \pm 0.16$ \\
\hline GPI & $1.239 \pm 0.04$ & $1.87 \pm 0.084$ & $1.61 \pm 0.06$ \\
\hline
\end{tabular}

Before the beginning of further treatment in patients with serorezistentnosti syphilis were observed increased rates of endogenous syndrome Institute - intoxication against benchmark data.
The sorptive capacity of erythrocytes ( SSE) to treatment was increased 1.6 times and was 51.6 \pm 0.7 (control - $31.7 \pm 0.64$ ) 
The level of middle peptides (SMP) prior to additional - Nogo treatment was increased to 1.66 times were $0,38 \pm 0.002$ (con trol $-0.229 \pm$ $0.001)$.

Calculated leucocyte intoxication index before treatment with the examined seroresis syphilis b yla increased and made 1, $91 \pm 0.12$ (control $1.215 \pm 0.04$ )

Hematological toxicity index appeared increased and amounted to $1.97 \pm 008$ ( control $1,239 \pm 0.04)$

Thus, it is revealed that in patients with serorezistentnosti syphilis prior to additional treatment parameters syndrome endogenous hydrochloric intoxication (ESA, SMP, LII, GUI) were elevated on relation - SRI control data.

The study of the level of indicators of the syndrome of endogenous intoxication after additional treatment showed that there was a significant decrease in ESE to $30.43 \pm 0.62$ (control $31.7 \pm 0,64$ ) and was lower than the control data.

SMP after additional treatment was also reduced and amounted to $-0.31 \pm 0.001$, but remained above the control $(0.229 \pm 0.001)$

LII the same beat was reduced and amounted to $1.75 \pm 0.16$ and remained above the control $(1.21 \pm 0.04)$

GPI after an additional holding of the treatment was reduced to $1,61 \pm 0.06$, but remained higher than the control $-1.239 \pm 0.04$.

\section{CONCLUSION}

Thus, it was revealed that in patients with seroresistance in syphilis, before the start of additional treatment, endotoxicosis is observed, manifested in increased indices of all studied parameters (ESE, SMP, LII, GPI). Additionally, the treatment carried out leads to a slight decrease in these indicators, but does not lead to the normalization of the data.

\section{REFERENCES}

1. Vyazmina E.S., Novikov V.V., Dobrotina N.A., Novikova S.I., Frigo N.V., Komarova V.D. The content of soluble forms of antigens $\mathrm{cd} 50$ and hla class $\mathrm{i}$ in seroresistant forms of syphilis // Bulletin of the Nizhny Novgorod University named after I.I. N.I. Lobachevsky. Series: Biology. 2001. No. 1. S. 39-44.

2. Ryshkova N.S., Esipova E.A., Kharakhordina Yu.E. Socio-epidemiological profile of pregnant women with seroresistant syphilis // In the collection: University science: a look into the future. Materials of the international scientific-practical conference dedicated to the 81st anniversary of Kursk State Medical University and the 50th anniversary of the Faculty of Pharmacy. In 3 volumes. 2016.S. 185-188.

3. Popov V.E., Esipova E.A., Schwartz N.E., Kharakhordina Yu.E. Seroresistant syphilis in pregnant women // In the book: St. Petersburg Dermatological Readings. collection of abstracts of the $X$ Jubilee scientific and practical conference of dermatovenerologists and cosmetologists. 2016.- S. 98.

4. Gafarov M.M., Nurislamov G.G., Mustafina G.R., Tukhvatullina Z.R. Modern features of the diagnosis and treatment of neurosyphilis // Bulletin of the Bashkir State Medical University. 2019.No. 1.P. 96-103. 
5. Shilova AA, Pankratov OV The problem of seroresistance in syphilitic infection // Medical News. 2015. No. 3. S. 26-28.

6. Barycheva L.Yu., Minasyan M.M., Chebotarev V.V., Odinets A.V. Immunophenotyping of blood cells in patients with sero-resistant, early and late latent syphilis // Modern problems of science and education. 2017. No. 5.P. 130. 